Marzenna Wiśniewska*

\section{Europejskie systemy organizacji teatrów}

DOI: http://dx.doi.org/10.12775/LC.2018.027

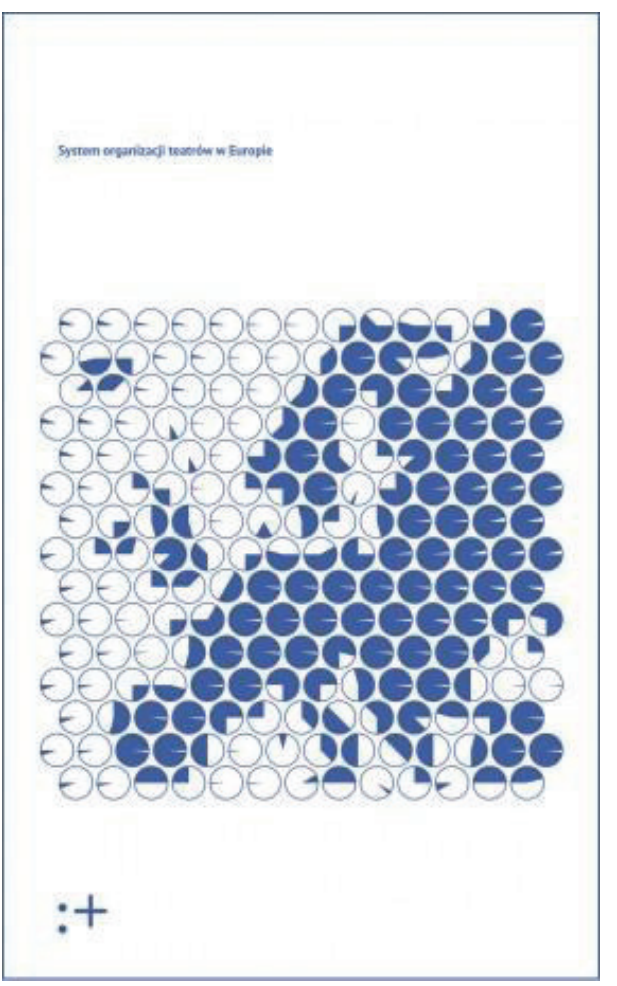

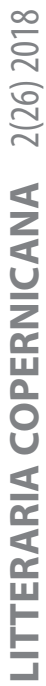

pojrzenie na teatr jako instytucję o swoistej strukturze organizacji, zarządzania, finansowania, również jako przedsiębiorstwo wpisane w transformacje sektorów i rynku kultury, w przemiany modeli produkcji i dystrybucji dóbr kultury do niedawna stanowiło raczej margines polskich badań

\footnotetext{
* Adiunkt w Katedrze Kulturoznawstwa Uniwersytetu Mikołaja Kopernika w Toruniu. E-mail: marzennaw@umk.pl.
}

teatralnych. Najnowsze opracowania w tym zakresie reprezentowały dotychczas głównie dwie książki: Przemiany organizacyjne teatru w Polscew latach 1989-2009Pawła Płoskiego (Warszawa 2009) oraz Ekonomika teatru Haliny Trzeciak (Warszawa 2011). Ukazały się one w momencie, który sprzyjał refleksji o miejscu teatru w systemie organizacji i działalności kulturalnej. Ogólnoświatowy kryzys ekonomiczny na początku drugiej dekady XXI wieku, który w wielu krajach spowodował cięcia w wydatkach na kulturę, wywołał dyskusje o metodach finansowania i rozliczania instytucji kultury z perspektywy zysku. W Polsce, po sporach wokół powoływania menedżerów teatrów, głośnym echem odbił się manifest środowisk teatralnych pod hasłem „Teatr nie jest produktem/ /Widz nie jest klientem". Doprowadził on do forum artystów z ówczesnym prezydentem Polski, Bronisławem Komorowskim (29 listopada 2012 roku), na którym dyrektorzy czołowych polskich scen wskazywali potrzebę zmian w ustawie regulującej działalność teatrów publicznych, m.in. w zakresie transparentności kryteriów konkursów na menedżerów scen, gwarancji długofalowego rozwoju instytucji i stabilizacji finansowania. Poza napięciami uwagę skupiały te ogniska życia teatralnego, w których sukces odnosiły rozwiązania modelujące teatr $\mathrm{w}$ duchu partycypacji kulturowej. Wałbrzych, Legnica, Bydgoszcz, Gdańsk stały się w polskim życiu teatralnym synonimami scen rozwijających performatywny model teatru, który przełamuje utrwalony schemat „teatru świątyni” i osadza instytucję w kontekście lokalnym, w przestrzeni publicznej, $\mathrm{z}$ jej aktualnymi problemami społecznymi, ale i potrzebą wzmacniania więzi.

Debatę o systemie organizacji życia teatralnego $\mathrm{w}$ Polsce wzmocnily $\mathrm{w}$ ostatnim czasie obchody dwustupięćdziesięciolecia teatru publicznego w Polsce (2015). 
Systematycznie opracowywane w tym czasie przez czasopismo „Teatr” mapowanie polskiego teatru oraz gorąca debata o misji i kształcie teatru narodowego/publicznego pozwalały zarówno uchwycić stałe elementy polskiego systemu teatralnego, jak i wskazać miejsca wymagające transformacji. Dyskusję podsycały liczne raporty z badań instytucji kultury, w tym m.in. wnioski Badania publiczności teatrów w stolicy, które upominały się o pogłębioną refleksję nad widownią teatralną. Równolegle do tych głosów ukazał się polski przekład książki Dragana Klaicia Gra w nowych dekoracjach. Teatr publiczny pomiędzy rynkiem a demokracja, inspirującej do wielopłaszczyznowego spojrzenia na miejsce teatru w systemie kultury. Klaić, pozostając głęboko przekonanym o potrzebie istnienia teatru publicznego w Europie, poddawał jednocześnie analizie jego strukturalne słabości oraz upominał się o rozszerzenie form artystycznego i społecznego oddziaływania teatru na tle konkurencyjnych zjawisk kulturalnych.

W kontekście tych procesów i wydarzeń z polskiego życia teatralnego w latach 2013-2016 toczył się międzynarodowy projekt badawczy Rozwój systemów organizacji teatrów w Unii Europejskiej, kierowany przez Karolinę Prykowską-Michalak z Katedry Dramatu i Teatru Uniwersytetu Łódzkiego. Jego efektem jest wydanie pod jej redakcją przez Instytut Teatralny im. Zbigniewa Raszewskiego pierwszego w Polsce kompendium o europejskich drogach rozwoju i przemian form organizacyjnych teatru pt. System organizacji teatrów w Europie. To publikacja, która rysuje złożony obraz europejskich systemów teatralnych, wnosi cenną metodologiczną różnorodność perspektyw badania teatru jako instytucji, łączy wymagania stawiane syntetycznym raportom z refleksją historycznoteatralną i kulturową. Socjologicznej analizie teatru towarzyszy $\mathrm{w}$ tym tomie perspektywa ekonomii kultu- ry, a ujęcia teoretyczne zyskują dopełnienie i uszczegółowienie w studiach przypadków. Imponujący jest zakres opracowania - obejmuje ono teatralne modele zachodnioeuropejskie: Francję, Wielką Brytanię, Niemcy, Austrię, Szwajcarię, rozwiązania w krajach nordyckich: Szwecji, Danii, Finlandii oraz wybrane systemy z Europy ŚrodkowoWschodniej: Litwy, Słowenii, Czech i oczywiście Polski. Autorzy zebranych tekstów analizują uwarunkowania i problemy poszczególnych systemów, osadzają organizację teatru w polityce kulturalnej państw i nakreślają najnowsze kierunki zmian. W tych zbliżeniach na wybrane systemy szczególną uwagę przyciągają oryginalne rozwiązania, dobre praktyki, które powinny zainteresować organizatorów życia teatralnego i środowiska artystyczne jako impulsy do nowych inicjatyw i autonomicznych rozwiązań na polu polskiego teatru.

Punktem wyjścia dla autorów tekstów zebranych $\mathrm{w}$ tomie jest teoria neoinstytucjonalizmu, która ujmuje teatr jako strukturę społeczną oraz organizację formalną z jej ulokowaniem „w różnych sektorach: publicznym, prywatnym, społecznym (czyli trzecim sektorze)", jak pisze PrykowskaMichalak we wstępie. Otwiera to drogę do interdyscyplinarnych analiz dających wgląd w system zasobów i normatywnych rozwiązań, na których są ufundowane poszczególne modele organizacji teatrów. Wspólna dla większości krajów europejskich tradycja poczucia odpowiedzialności społecznej za teatr sprawia, że znaczący udział w kształtowaniu życia teatralnego mają subsydiowane teatry sektora publicznego. Stabilne organizacyjnie i finansowo, zmagają się jednak z poważnym problemem, który sprzyja zakusom poddania teatrów prawom wolnego rynku, mowa tu o syndromie tzw. choroby kosztów (termin Williama Boumolla i Williama Bowena), czyli luce między przychodami i kosztami instytucji. Wynika 
ona m.in. z dominacji stałych kosztów osobowych (m.in. utrzymywanie tradycji teatru zespołowego) w sektorze działań artystycznych, których obniżenie nie jest obojętne dla jakości przedsięwzięć i ich trwałego oddziaływania kulturowego. Przeciwdziałanie „chorobie kosztów” to jedno z głównych wyzwań ekonomicznych dzisiejszych teatrów subsydiowanych, determinujące obowiązek pozyskiwania dodatkowych źródeł finansowania. I tu warto powiedzieć za analizą Iny Pukelyte, porównującą efektywność litewskich teatrów państwowych i scen niezależnych, że w warunkach kultury projektowej i wielokanałowości finansowania ogólnie lepiej radzą sobie teatry offowe. Kolejnym wspólnym doświadczeniem teatrów europejskich są przekształcenia zmierzające do uelastyczniania systemu ich organizacji. Dotyczy to zarówno rozmaitości form organizacyjno-prawnych (obok instytucji artystycznych, teatry działają jako różne typy spółek, organizacji pozarządowych, kooperacji instytucji oraz przedsiębiorstwa prywatne), jak i reformy zatrudniania pracowników teatralnych. Dzisiejsze instytucje działają $\mathrm{w}$ napięciu między tradycją teatru repertuarowego ze stałym zespołem a tendencjami uwalniania rynku pracy. Problem etatyzacji w teatrach $\mathrm{w}$ wielu krajach regularnie podlega krytyce jako czynnik stagnacji zespołów i źródło kosztów stałych, co wzmacnia praktyki zatrudniania w systemie projektowym i zjawisko outsourcingu usług. Zarazem jednak ważnym wyzwaniem staje się systemowe zabezpieczenie pracowników branży teatralnej, którzy przy nieetatowych formach angażu tracą gwarancję stałości dochodów i wiele przywilejów pracowniczych (ubezpieczeniowych, finansowych, prawnych). W tej chwili tylko Francja ma najbardziej spójne rozwiązania w tym zakresie, o czym pisze Małgorzata Dąbrowska.

Przechodząc do bardziej szczegółowego spojrzenia na tom System organiza- cji teatrów $w$ Europie, warto podążyć za przyjętym $\mathrm{w}$ publikacji podziałem na pięć części, z których ostatnia to studia przypadków dopełniające wybrane zagadnienia z głównych bloków. W dwóch pierwszych częściach śledzimy dwa wyraziste, choć wewnętrznie niejednorodne, modele, które $\mathrm{w}$ teorii zmian instytucjonalnych są określane jako decentralistyczny i federalistyczny. Warianty pierwszego $\mathrm{z}$ nich reprezentuje życie teatralne we Francji, w Wielkiej Brytanii i w Polsce. Nieprzypadkowo część tę otwiera tekst Piotra Olkusza Organizacja życia teatralnego we wspótczesnej Francji, ponieważ wyostrza on paradoks charakterystyczny dla systemów decentralistycznych - wrogość do centralizacji życia kulturalnego jest wprzęgnięta $\mathrm{w}$ oczekiwanie zaangażowania państwa w kulturę. Na tym swoistym godzeniu wody $\mathrm{z}$ ogniem opierały się najważniejsze trendy w powojennej polityce kulturalnej Francji. W myśl idei demokratyzacji kultury i zasady solidarności społecznej architekci decentralizacji teatru, których skrupulatnie odnotowuje Olkusz (z najważniejszą dla francuskiego życia teatralnego Jeanne Laurent na czele), położyli nacisk na powołanie teatru subwencjonowanego poza Paryżem. Odbudowa życia teatralnego na prowincji odbyła się głównie przez trzy modele instytucji, co do dziś ma znaczące konsekwencje dla francuskiego systemu teatralnego. Wspomniana Laurent powołała do tego celu narodowe centra dramatyczne, czyli publiczne teatry na prowincji finansowane w ramach partnerstwa przez rząd centralny i władze lokalne. Bardzo często powstawały one wokól już działającego lokalnie twórcy, co wytworzyło zjawisko teatrów jako dzieł życia jednego artysty - takie źródła ma np. zespół Jeana Dastéa z SaintÉtienne. Drugą formą decentralizacji było wprowadzenie przez André Malraux sieci domów kultury zaplanowanych jako centra sztuki z dominującą rolą teatru, służą- 
ce spotkaniu twórców (profesjonalistów i amatorów) z odbiorcami. Do subwencjonowanych scen lokalnych dołączyły również stałe zespoły lub grupy niezależne powstające $\mathrm{z}$ prowincjonalnych grup teatralnych działających wcześniej jako spółki (do takich należał Théâtre du Soleil Ariane Mnouchkine). Warunki sprzyjające rozwojowi różnorodnego organizacyjnie i artystycznie sektora teatralnego, paradoksalnie, konstatuje Olkusz, nie doprowadziły jednak do „powstania silnych placówek o dużym potencjale twórczym rozpoznawalnych na mapie kulturalnej Europy. Obserwuje się dosyć dużą homogenizację poziomu instytucji należących do jednej kategorii”. Teatr francuski ma swoich widzów, spektakle są grane dla pełnej publiczności, najważniejsze festiwale teatralne (np. w Awinionie) mają rangę europejską, niemniej „francuski model polityki kulturalnej trzeszczy w szwach” i wzmagają się napięcia między tendencjami decentralizującymi a mimowolnie dokonującymi się procesami centralizacji. Naciski na większą liczbę wydarzeń kulturalnych, pogorszenie sytuacji finansowej instytucji przy spowolnieniu gospodarczym, złożony system współprowadzenia instytucji, znaczna rola rządowej biurokracji, brak luźnych środków, likwidacja stałego zatrudnienia w branży teatralnej - skutkują zdaniem krytyków obecnego systemu organizacji teatrów we Francji „estetyką kulturalnej przeciętności”, „artystycznej poprawności” scen, siecią powiązań między scenami (m.in. przez duży udział koprodukcji w działalności repertuarowej), utrudniających rewolucję artystyczną. Wzmacniane instytucje lokalne w wielu przypadkach spełniają rolę beneficjenta ambitnych działań artystycznych powstających w stolicy, co minimalizuje ich wpływ na rozwój sztuki teatru i sprzyja w efekcie centralizacji życia teatralnego. Potencjał centralizacyjny objawiła też likwidacja stałych zespołów aktorskich w teatrach subwencjonowanych - gros aktorów przeniosło się do stolicy i największych miast.

Tekst Olkusza stanowi bardzo dobry kontekst dla dyskusji o kierunkach zmian w polskim systemie teatralnym. Prezentuje np. interesujące rozwiązanie finansowania „scen działających na mocy porozumienia” $\mathrm{z}$ dotacją państwową $\mathrm{w}$ wysokości dziesięciu procent budżetu w uznaniu dla bieżącej i planowanej działalności. Praktyka ta wzmacnia szczególnie niezależny ruch teatralny $w$ tworzeniu długotrwałych $\mathrm{i}$ jakościowo istotnych działań artystycznych, które trudno rozwijać tylko na podstawie środków projektowych. Warta uwagi jest również wynikająca z długotrwałej polityki kulturalnej Francji interdyscyplinarność instytucji teatralnych.

Dopełnieniem opracowania Olkusza jest studium Małgorzaty Dąbrowskiej, System zasitków dla pracowników branży teatralnej $i$ widowisk - punkt zapalny francuskiej polityki kulturalnej, które daje wgląd w konsekwencje francuskiej reformy zatrudnienia w teatrach. Autorka analizuje likwidację stałego zatrudnienia we francuskiej branży teatralnej na tle ogólnych procesów gospodarczych wspierających system samozatrudnienia oraz pokazuje złożoność prawnych, społecznych i gospodarczych rozwiązań towarzyszących ustanowieniu statusu zawodowego intermittent $d u$ spectacle, przeznaczonego dla osób pracujących w systemie umów-zleceń i narażonych na okresowe przerwy w pracy. Tekst Dąbrowskiej to lektura obowiązkowa w kontekście polskiej debaty o zmianie polityki zatrudnienia $w$ instytucjach artystycznych.

Decentralistyczny charakter systemu angielskiego, o którym pisze Jolanta Sławińska-Ryszka (Ku pluralizmowi. Organizacja teatrów Wielkiej Brytanii), wynika z kształtującego się na przestrzeni wieków ekonomicznego podejścia Brytyjczyków do 
wszelkiej działalności kulturalnej. Zasady przedsiębiorczości decydowały o kształcie życia teatralnego już Anglii elżbietańskiej kompanie teatralne oparte na systemie akcyjnym były popularnym modelem działalności, dając przykład pierwszemu w Europie tak dobrze rozwiniętemu teatrowi komercyjnemu. Naturalną cechą angielskiego systemu teatralnego jest nastawienie dotowanych instytucji na wolnorynkowe warunki działalności, promowanie związków między sztuką i biznesem (przy czym zachęta do zwiększania efektywności ekonomicznej zostaje połączona $\mathrm{z}$ gwarancję nieobniżania $\mathrm{z}$ tego tytułu dotacji państwowej) oraz elastyczność. Autorka podkreśla systemowy tryb wdrażania dobrych praktyk, jak choćby wsparcie współpracy sektora publicznego i prywatnego przez specjalne ulgi podatkowe czy rządowe rozwiązania promujące idee fundraisingu. Ma to również wpływ na realne oddziaływanie ruchów związkowych i społecznych organizacji na rzecz teatru na sprawy życia teatralnego, czego przykładem jest BECTU, które wynegocjowało z rządem wieloletni program podwyżek płacy minimalnej dla pracowników obsługi widowni. Interesującym elementem systemu angielskiego jest otwarta lista narodowych instytucji kultury. W praktyce oznacza to, że co trzy lata w ramach programu Narodowe Portfolio następuje otwarty nabór aplikacji dla instytucji, które swoją działalnością gwarantują spełnianie założeń narodowej strategii rozwoju kultury. Rozwiązanie to jest pomyślane jako stosunkowo bezpieczne dla instytucji o publicznym statusie (sprzyja też regularnej weryfikacji ich misji) oraz umożliwia zmiany w rozkładzie środków i poszerzanie listy o nowe podmioty, co rzeczywiście się dzieje. Drugi ciekawy przykład to stworzenie teatrów dotowanych ze statusem charity (np. National Theatre, Royal Shakespeare Company), który uprawnia do ulg podatkowych na wydatki kwalifikowa- ne produkcji teatralnych (dwadzieścia procent dla widowisk teatralnych, dwadzieścia pięć - dla działalności objazdowej). Ten system wprowadził kolejne obok głównych programów rządowych źródło finansowania działalności teatralnej, zarazem dając wgląd w bieżące informacje o kosztach produkcji teatralnej.

Oczywiście angielski teatr ma swoje problemy. Na tle silnego przemysłu teatralnego, bo o takim zjawisku można mówić w przypadku Londynu, gdzie na scenach padają rekordy frekwencji - piętnaście milionów widzów na West Endzie w 2013 roku, musical Charlie and the Chocolate Factory, który w ciągu dwóch lat od premiery obejrzało ponad milion widzów - trudno zaistnieć niekomercyjnym i niszowym przedsięwzięciom teatralnym, które są źródłem eksperymentów i poszerzają pole teatru. Mimo wielokanałowych systemów finansowania nie udaje się również uniknąć dysproporcji w finansowaniu życia teatralnego stolicy i prowincji.

Pierwszą część tomu zamyka artykuł Pawła Płoskiego Od decentralizacji do decentralizacji. System teatralny $w$ Polsce. Autor rysuje panoramę procesów decentralizacyjnych $\mathrm{w}$ polskim życiu teatralnym od pierwszych lat odwilży w socjalistycznej polityce kulturalnej (po 1954 roku), przez transformację po 1989 roku, która przyniosła dalekosiężne zmiany organizacyjne i ustawowe dla działalności teatralnej (m.in. zmiana organizatorów i sposobów finansowania), po dzisiejsze nowe wyzwania związane choćby $\mathrm{z}$ tematem współprowadzenia teatrów przez organy państwowe i samorządowe. Cenną zdobyczą wczesnej decentralizacji była zmiana „geografii wydarzeń” teatralnych: rozwój lokalnych oddolnych inicjatyw pod patronatem nieteatralnych instytucji lub towarzystw kulturalnych, powstanie festiwali inicjowanych przez lokalne środowiska teatralne, których pionie- 
rem był Festiwal Teatrów Polski Północnej w Toruniu (1959). Po 1989 roku procesy decentralizacji łączyły się z przekazywaniem scen samorządom regionalnym i miejskim, ze zjawiskami prywatyzacji (nierzadko tzw. dzikiej prywatyzacji), rozwojem nowych form organizacyjnych teatrów (stowarzyszenia, fundacje, spółki), stymulacją nowych kanałów finansowania, szczególnie z regionalnych środków unijnych, które odegrały znaczącą rolę w przebudowie i modernizacji wielu polskich scen (m.in. Teatr Baj Pomorski w Toruniu). Jednym ze znaków dzisiejszych tendencji decentralistycznych jest natomiast tworzenie nowych scen przez gminy i samorządy, bardzo często w odniesieniu do modelu teatru impresaryjnego. Widać w tym z jednej strony aspirację lokalnych środowisk do posiadania własnych scen teatralnych, z drugiej zaś próbę wypracowania nowej struktury organizacyjnej, która godzi warunki działania scen subsydiowanych z zasadami wolnorynkowych instytucji. Efekty artystyczne i organizacyjne takich modeli będzie można oceniać dopiero za parę lat.

Trochę szkoda, że w szerokim historyczno-teatralnym ujęciu Płoskiego nie wybrzmiały mocniej wątki naświetlające kilka problemów istotnych dla dzisiejszego systemu teatralnego w Polsce. Polski teatr zmaga się obecnie z konsekwencjami przemian ustawowych o instytucjach kultury, co objawia się $\mathrm{w}$ nagłaśnianych medialnie konfliktach wokół wyboru dyrektorów, ale ma również związek z napięciami wynikającymi z wprowadzania pozaetatowych form zatrudnienia pracowników artystycznych czy outsourcingu usług w zakresie rzemiosł teatralnych. Problemem polskiego życia teatralnego jest dysproporcja finansowania między centrum i prowincją, mały zakres systemowych rozwiązań stymulujących poszukiwanie i wykorzystywanie dodatkowych źródeł wsparcia działalności teatrów oraz dominacja danych ilościowych, statycznych w ocenie artystycznej działalności teatrów. Z perspektywy tendencji $\mathrm{w}$ polskim systemie decentralistycznym warte odnotowania są dwa zjawiska: rozwój multidyscyplinarnego charakteru teatrów oraz silny ruch związany ze strategiami rozwoju widowni, oparty na budowaniu więzi teatru z lokalną widownią oraz najbliższym otoczeniem.

Niektóre z tych wątków podejmuje Joanna Szulborska-Łukaszewicz w studium Miejsce teatru $w$ polityce kulturalnej państwa i polskich samorzadów. Teatry krakowskie, pisanym z pozycji ekonomiki teatru i zarządzania instytucjami. Dodaje ono do tekstu Płoskiego (czerpiąc też z jego ustaleń w przywołanej książce Przemiany polskich teatrów... ) przegląd form organizacyjnych teatrów polskich, analizę miejsca teatru w Narodowej Strategii Rozwoju Kultury oraz ocenę uwarunkowań ekonomicznych polskich scen. Autorka zwraca uwagę na konflikt oczekiwań stawianych przed teatrami: mają one oferować ambitny program merytoryczny i prowadzić rozbudowaną działalność, a zarazem przynosić zyski i reagować na reguły wolnego rynku. Zasadne jest wtedy pytanie, jak w takim systemie wspierać eksperymenty artystyczne, podejmować ryzykowne przedsięwzięcia czy promować niszowe zjawiska, które dopiero torują sobie drogę do odbiorców.

Różnorodności organizacyjnej życia teatralnego sprzyja opisany w drugiej części tomu model federalistyczny oparty na silnej autonomii lokalnych struktur, dominujący w Niemczech, Austrii i Szwajcarii. Już tytuł artykułu Karoliny Prykowskiej-Michalak Organizacja teatrów w Niemczech. Szesnaście systemów sygnalizuje heterogeniczność rozwiązań niemieckich, będących konsekwencją usankcjonowanej historią tego kraju idei federalizmu i suwerenności kulturowej. Szesnaście krajów związkowych jako jed- 
nostek administracyjnych daje $\mathrm{w}$ efekcie tyle samo systemów organizacji kultury, z których każdy stanowi raczej swoiste case study niż model do powielania, co podkreśla autorka. Znamienną cechą niemieckiej organizacji życia teatralnego jest silna pozycja kultury muzycznej, która ukształtowała tradycję teatrów wielodziałowych, tzn. scen złożonych z kilku autonomicznych działów/zespołów, np. opery, dramatu, teatru tańca, a ostatnio dodatkowo teatru dla dzieci i młodzieży lub eksperymentalnego. Co ciekawe, trend wielobranżowych instytucji teatralnych sprawdza się raczej poza największymi ośrodkami kulturalnymi. Prykowska-Michalak skrupulatnie i kontekstowo analizuje zarówno w tym tekście, jak i zamieszczonym w części Studia przypadków opracowaniu pt. Teatry niemieckie poszczególne typy scen: teatry publiczne (Staatstheater, Landestheater, Stadttheater), teatry wolne (Freie Theater, Freie Bühnen), teatry prywatne. Najpopularniejszą formą organizacyjno-prawną teatrów publicznych jest przedsiębiorstwo komunalne, szczególna forma spółki publicznej (Regiebetrieb), ale niemieckie sceny publiczne i prywatne rejestrują się również jako spółki cywilne, spółki z ograniczoną odpowiedzialnością czy fundacje lub stowarzyszenia. „Wielość rozwiązań formalnych - pisze PrykowskaMichalak - wynika z poszukiwania kompromisu między niezależnością od lokalnych władz a potrzebą otrzymywania odpowiednich subwencji. Zmiany form organizacyjnych dyktowane są koniecznością zwiększenia rentowności oraz odpowiedzialności całego zespołu nie tylko za swoje miejsce pracy, ale przede wszystkim za ofertę artystyczną". W zestawie rozmaitych form organizacji teatru uwage zwraca nowy model wypracowany na początku tego wieku w Hildesheim (tzw. Hildesheimer Modell), który polega na sieciowaniu współpracy teatralnej kilku instytucji: teatru publicznego i np. uniwersytetu, teatru wolnego, lokalnej organizacji, oraz opiera się na „aktywnym udziale mieszkańców w tworzeniu ich teatru". Niemcy uważnie przypatrują się tym nowym rozwiązaniom organizacyjnym, ponieważ szukają planów naprawczych na diagnozowany tam od kilku lat kryzys spowodowany odpływem widzów oraz wspominaną już wcześniej tzw. chorobą kosztów. W niemieckiej debacie o zaniedbanych obszarach niemieckiego życia teatralnego są wskazywane: wspólpraca z młodzieżą i edukacja teatralna oraz wykorzystanie wieloetnicznego potencjału publiczności niemieckiej.

Organizacja teatrów w Austrii Moniki Wąsik prezentuje utrwalony przez przełomy polityczne całego XX wieku model teatru austriackiego jako strażnika tradycji i tożsamości narodowej, z centralną pozycją Wiednia i dominującą rolą scen narodowych traktowanych priorytetowo i reprezentacyjnie. Austria może poszczycić się ponadprzeciętną frekwencją widzów w teatrach na tle innych krajów europejskich - i jest to cały czas tendencja zwyżkowa. W Austrii działa w tym momencie największy na świecie koncern teatralny Bundestheater-Holding $\mathrm{GmbH}$, któremu podlegają jako spółki-córki sceny narodowe - Burgtheater, Wiener Staatsoper, Volksoper oraz Theaterservis. Ale, jak pisze Wąsik, jest to kolos na glinianych nogach, przeżywający ogromny kryzys finansowy. Znacznie lepiej na tym tle wypadają tzw. duże sceny wchodzące w skład Zjednoczonych Scen Wiednia, wiedeńskie teatry prywatne (np. Schauspielhaus Wien), teatry średnie i „wolne sceny”, tzn. teatry alternatywne i amatorskie. Wąsik zwraca uwagę na skuteczność Wiedeńskiej Reformy Teatrów, która, co ważne w kontekście niepewności kultury projektowej, wzmocniła wieloletnie projekty i planowanie działań z wyprzedzeniem. Przełożyło się to na sukcesy festiwali teatralnych (np. 
Wiener Festwochen) oraz wsparło eksperymentalne przedsięwzięcia (przykładem jest Schauspielhaus Wien).

Specyfikę federalnego państwa zdaje się najlepiej wykorzystywać system teatralny w Szwajcarii, o którym pisze Małgorzata Ćwikła. Studium Krajobraz teatralny Szwajcarii - ujęcie organizacyjne jest interesujące z kilku powodów. Po pierwsze, to jedno z nielicznych w Polsce przybliżeń szwajcarskiego teatru, który, jak pisze autorka, $\mathrm{z}$ reguły znika na tle swoich wielkich sąsiadów, Francji, Niemiec i Włoch, a warto wspomnieć, że jego najnowsze karty znaczą takie osobowości, jak Christoph Marthaler prowadzący scenę w Zurychu (2000-2004) czy Milo Rau, twórca głośnego dokumentu teatralnego o ludobójstwie w Ruandzie Hate Radio. Szwajcarski system jest intrygującym przykładem ze względu na wielojęzyczność i wielokulturowość tego kraju trudno bowiem mówić w tym wypadku o jednym teatrze, raczej o życiu teatralnym kręgów językowych: niemieckim, włoskim, francuskim i retoromańskim. Organizacja teatrów w Szwajcarii to ponadto pole obserwacji bardzo dobrych efektów ścisłego powiązania odpowiedzialności społecznej za kulturę z systemem długofalowego planowania. Oczywiście nie bez znaczenia jest bardzo dobra sytuacja ekonomiczna Szwajcarii. Ćwikła prezentuje system teatralny $\mathrm{w}$ dwóch obowiązujących $\mathrm{w}$ nim porządkach. Pierwszy to podział na teatry repertuarowe (miejskie), niezależne i amatorskie, drugi podział wiąże się z regionami językowymi. Cechą wyróżniającą życia teatralnego Szwajcarii jest wyrazistość profili teatrów oraz bardzo duży w nim udział teatru amatorskiego, traktowanego jako narzędzie społeczne, służące pobudzaniu krytycznego myślenia, utrwalaniu wspólnoty oraz rozwiązywaniu kwestii integracji. Podobną rolę odgrywają interdyscyplinarne przedsięwzięcia dla dzieci i młodzieży, w których młodzi ludzie są współtwórcami (np. Festiwal Blickfelder). Wzmacnianie współodpowiedzialności za kulturę przekłada się również na dobrze pomyślane mechanizmy angażowania indywidualnych donatorów w finansowanie teatrów. Do popularnych dobrych praktyk należy tworzenie przy teatrach „klubów przyjaciól”, których członkowie płacą składki umożliwiające im udział $\mathrm{w}$ dodatkowych działaniach instytucji, system abonamentowy dostosowany do indywidualnych preferencji teatralnych oraz rozwój i dostępność prostych form domatorskiego wsparcia pojedynczych przedstawień.

Spośród trzech spojrzeń na systemy teatralne w krajach nordyckich swego rodzaju zadziorność badawczą i gotowość stawiania prowokacyjnych tez prezentuje artykuł Alette Scavenius i Kim Skjoldager-Nielsen Wpływ inicjatywy prywatnej na rozwój duńskiego systemu teatralnego. Rozpoczynająca ten blok Dorota Kubiak, autorka Organizacji szwedzkiego systemu teatralnego charakteryzuje system w Szwecji jako stabilny i oparty na zrównoważonym rozwoju wpisanym w politykę kulturalną państwa. I zdawać by się mogło, że tę cechę można by przypisać ogólnie krajom nordyckiego kręgu geograficzno-kulturowego. Tymczasem Scevenius i Skjoldager-Nielsen podważają takie spojrzenie i stawiają radykalną tezę: „Wyniki naszej pracy kwestionują powszechne przekonanie o tym, że Dania jest krajem, w którym rząd wspiera życie intelektualne. Podważamy także zasadność postrzegania rozwoju systemu teatralnego jako efektu sprawnej polityki kulturalnej i umiejętnego podejmowania decyzji politycznych. [...] W historii teatru w Danii prywatne inicjatywy odegrały znacznie większą rolę w rozwoju systemu teatralnego niż wcześniej przypuszczano”. Odwołując się do teorii aktorów życia społecznego Knuta Kjeldstadli i teorii systemów społecznych Anthony'ego 
Giddensa, autorzy zwracają uwagę na nośność badawczą analizy takich aspektów, jak m.in. usytuowanie geograficzne, warunki naturalne oraz dostęp do technologii, poszerzając tym samym pole rozważań o uwarunkowaniach rozwoju systemu teatralnego. Za siłę napędową rozwoju duńskiego systemu teatralnego autorzy uznają podmiotową aktywność osób i grup (np. klasy średniej), która przekłada się na budowanie struktur stwarzających im odpowiednie warunki do społecznej sprawczości. Zwracają uwagę na pomijany często $\mathrm{w}$ badaniach teatralnych kontekst ruchów społecznych, które do początku XIX wieku tworzyły w Danii klimat „szaleństwa teatralnego”: stowarzyszeń i klubów teatralnych, teatrów amatorskich, a później również uniwersytetów ludowych. Wskazują związek między zdolnością lokalnych przedsiębiorców do zarabiania i ponoszenia ryzyka inicjatyw a rozwojem działalności i infrastruktury kulturalnej, co obrazuje intensywność i rozmaitość form życia teatralnego w Jutlandii.

O szwedzkim teatrze wiele mówią statystyki: w kraju zamieszkanym przez dziesięć milionów obywateli sprzedaje się sześć milionów biletów do teatru. Przywołana już Dorota Kubiak daje szeroki opis historii rozwoju teatru w Szwecji od scen dworskich do rządów socjaldemokracji, by pokazać konteksty modelujące status poszczególnych typów scen: narodowych, regionalnych, miejskich, niezależnych i prywatnych. Obecny szwedzki system teatralny to efekt kilku procesów. Rozwijana po wojnie idea państwa opiekuńczego usankcjonowała zasadę wspierania instytucji i indywidualnych artystów z państwowych dotacji. Zainicjowane przez politykę rządową teatry regionalne, związane ściśle z lokalnym środowiskiem oraz ekspansja teatru dla dzieci i młodzieży, która wynika z postawienia silnego akcentu na upowszechnianie edukacji artystycznej, pobudziły tendencje decentralizacji życia teatralnego. $\mathrm{W}$ ostatnich latach przyczyniły się one do redystrybucji środków finansowych i zwiększenia udziału władz lokalnych w kształtowaniu życia kulturalnego. Jako że jedną z główną zasad polityki kulturalnej Szwecji jest równość dostępu do produktów kultury dla wszystkich obywateli, ważne miejsce w programie teatralnym zajmują działania na rzecz grup defaworyzowanych. Ze wsparcia dla takich przedsięwzięć chętnie korzystają teatry niezależne, co znacząco wpłynęło na przeprofilowanie ich działalności.

Część nordycką tomu zamyka tekst Laury Gröndahl Amatorskie korzenie fińskiego systemu teatralnego, w którym powraca myśl o oddolnych inicjatywach jako sile sprawczej rozwoju struktur teatralnych. Autorka pisze: „Nie bez powodu fiński teatr nazywany był teatrem ludzi, a Finowie ludźmi teatru. [...] Statystycznie każdy obywatel Finlandii wybiera się do teatru raz w roku”. Na pięć i pół miliona mieszkańców przypada 188 profesjonalnych teatrów i około 130 grup teatralnych dotowanych z budżetu państwa. Zespoły tych scen $\mathrm{w}$ znacznym stopniu rekrutują się $\mathrm{z}$ ruchu amatorskiego, w którym Finowie uczestniczą ochoczo jako równoległej formie życia teatralnego. Rozbudowany system teatralny jest paradoksalnie źródłem problemów fińskiego teatru. Gröndahl zwraca uwagę, że gęsta sieć teatrów miejskich z nieelastycznymi strukturami organizacyjnymi, zbyt duże sale w stosunku do potrzeb, kurczenie się publiczności w ostatnich latach i ograniczenia finansowe to poważne wyzwanie dla systemu. W reakcji na nie Finowie wspierają obecnie społeczne i edukacyjne praktyki teatralne inspirowane działalnością Augusto Boala czy doświadczeniami Rimini Protokoll.

Przedostatnia część tomu jest poświęcona systemom teatralnym nowych państw Unii Europejskiej. Sylwia Czachór w tekście 
Czeski system teatralny pokazuje złożone konteksty modelowania teatru czeskiego: rolę idei instytucji krzewiącej kulturę narodową i umacniającej więzi społeczne, silny wpływ niemieckich i austriackich tradycji (m.in. dominacja w infrastrukturze teatralnej teatrów wielodziałowych), procesy transformacji po 1989 roku i decentralizacja życia teatralnego, która, podobnie jak w Polsce, przyczyniła się do rozkwitu niezależnych teatrów o zróżnicowanej strukturze organizacyjnej oraz sektora komercyjnego. W czeskim systemie teatralnym są przedsiębiorstwa użyteczności publicznej, organizacje pożytku publicznego, spółki i stowarzyszenia, chętnie wybierane ze względu na autonomię oraz dostęp do programów grantowych dla organizacji pozarządowych. Czachór zwraca wagę na duże nasycenie rynku teatralnego w Czechach każde większe miasto ma profesjonalną scenę, wiele $\mathrm{z}$ nich prowadzi wielodziałowe teatry, wspiera ruch niezależny $i$ amatorski. Efektem transformacji po 1989 roku jest rozwój teatrów określanych jako „stagione”, o czym już szczegółowo pisze Czachór w zamykającym cały tom studium Stagione jako popularny system organizacyjny we wspótczesnym teatrze czeskim. Odchodzą one od konwencjonalnego modelu organizacji teatru repertuarowego, ze stałym zespołem, na rzecz „przestrzeni eksperymentalnych” czy „wielofunkcyjnych centrów kultury”, które działają w trybie projektów z zapraszanymi do nich artystami. Elementem pozytywnie wspierającym rozwój systemu teatralnego w Czechach są zdaniem Czachór dyskusje ekspertów publikowane na łamach czasopism specjalistycznych oraz badania Instytutu Sztuki i Teatru.

System organizacji kultury w Słowenii, o którym pisze Krištof Jacek, nosi znamiona postkomunistycznej transformacji połączonej w wypadku kraju byłej Jugosławii z procesem odzyskiwania autonomii narodowej.
To zdeterminowało dominujący udział państwa w finansowaniu kultury (interwencjonizm finansowy), co z kolei spowolniło proces restrukturyzacji organizacji teatrów. Tymczasem kryzys ekonomiczny pod koniec pierwszej dekady tego wieku i znaczne ograniczenia w wydatkach państwowych na kulturę wywołały potrzebę przyspieszonego przejścia na menedżerski system zarządzania kulturą. Oznacza on m.in. znaczne ograniczenie stałych etatów dla pracowników artystycznych, presję na zwiększenie liczby odbiorców i zmniejszenie kosztów produkcji. Jak podsumowuje Kozak, najwyższą cenę za dostosowywanie teatru do zasad wolnego rynku płacą obecnie sami twórcy, stąd regularne protesty tego środowiska.

Temat zatrudnienia $\mathrm{w}$ instytucjach teatralnych i konfliktu między uelastycznianiem struktury organizacyjnej a gwarancją stabilności finansowej pracowników artystycznych powraca w artykule Iny Pukelytė Litewski system organizacji teatrów. Porównanie efektywności działania teatrów państwowych oraz scen niezależnych. Restrukturyzacja zatrudnienia była pierwszym z elementów reorganizacji systemu teatralnego na Litwie po 1989 roku. Towarzyszyły jej głośne konflikty w środowisku teatralnym, ale otwarcie się na nowe rozwiązania, np. kontraktów czasowych dla artystów, umożliwiło zatrudnianie młodych aktorów i poprawiło poziom wielu zespolów. Potrzebę zmian systemu organizacji życia teatralnego wnosity coraz liczniej pojawiające się niezależne grupy teatralne, które wydały takie zjawiska, jak autorski teatr Oskarasa Koršunovasa. I nie chodziło tylko o kwestię dystrybucji środków finansowych, ale również o ocenę efektywności działalności. Artykuł Pukelytè odpowiada na pytanie o model badania efektywności działalności teatralnej, który to temat jest nieustannie dyskutowany $\mathrm{w}$ kontekście częstych utyskiwań na ilościowy paradygmat oceny in- 
stytucji. W badaniach empirycznych i ankietach jakościowych przeprowadzonych na Litwie poddano analizie dwie formy działalności teatralnej - teatry państwowe oraz sceny niezależne, uwzględniając następujące kryteria: podstawy prawne, budżet, frekwencję widzów, model zarządzania zasobami ludzkimi. Przytoczone przez Pukeltè wyniki badań porównawczych według tych kryteriów potwierdziły paradoksy systemu teatralnego, którym podlega nie tylko Litwa. Gwarancja dotacji dla teatrów państwowych sprzyja trwałości instytucji, ale zarazem stagnacji organizacyjnej i artystycznej. Tymczasem przymus projektowego pozyskiwania środków przez sceny niezależne wymusza ich dużą aktywność i odwagę artystyczną, co skutkuje znaczącym udziałem młodych artystów i aktorów $\mathrm{w}$ procesie twórczym, większą swobodą działania poza własną siedzibą oraz regularną obecnością na festiwalach i rozgłosem międzynarodowym. Teatry niezależne generują dochód, w którym spory udział mają wpływy z wyjazdów zagranicznych, $\mathrm{w}$ czym prym wiedzie wspomniany teatr Oskarasa Koršunovasa (OKT) czy wileński Fort Sztuki (Meno Fortas) Eimuntasa Nekrošiusa.

Tom System organizacji teatrów w Europie $\mathrm{w}$ pełni odzwierciedla obserwację wspomnianego już Dragana Klaicia, który pisał, że „dziedzina sztuk performatywnych kwitnie w Europie oszałamiającą wręcz liczbą form organizacyjnych, modeli produkcji i dystrybucji, systemów i źródeł publicznego finansowania, teatrów, festiwali, pracowni, stowarzyszeń zawodowych, branżowych instytutów i organizacji”. W systematycznym opracowaniu zwraca uwagę związek między tą różnorodnością a aktywnością lokalnych, oddolnych, niezależnych środowisk na rzecz teatru. Wspieranie tego typu inicjatyw zdaje się jedną z najważniejszych recept nie tylko na zachowanie żywotnej roli teatru w kulturze, ale i otwarcie instytucji teatralnej na performatywny model organizacji i zarządzania. Ostatnio upomniała się wręcz o to sama publiczność. Toruńska akcja „Teatr jest nasz" po zawieszeniu konkursu na stanowisko dyrektora Teatru im. Wilama Horzycy, działania Stowarzyszenia Widzów Teatrów Publicznych we Wrocławiu czy list protestacyjny i petycje do senatu Berlina przeciwko demontażowi berlińskiej Volksbühne po rezygnacji z przedłużenia kontraktu dla Franka Castorfa to tylko kilka przykładów wołania o poszanowanie decentralistycznej polityki, w której znajdzie się również miejsce na głos tych, którzy wypełniają sale teatralne. 